\title{
Lingual epilepsia partialis continua in neurocysticercosis
}

回

Figure 1 MRI (left frontal cysticercal granuloma)

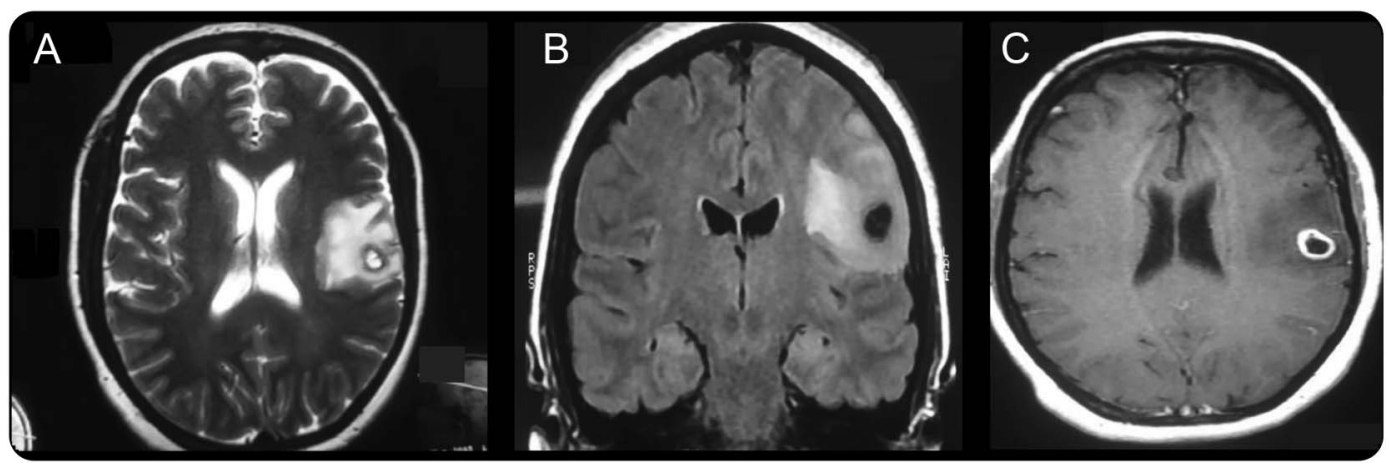

An oval lesion hyperintense on T2 (A) and hypointense on fluid-attenuated inversion recovery (B) with ring enhancement on postcontrast T1 (C) with an eccentric dot-like scolex located in the left inferior frontal gyrus is consistent with neurocysticercosis.

A 60-year-old woman presented with focal clonic movements of her face and abnormal movements of her tongue for 5 months. An MRI revealed a ring enhancing lesion, suggestive of a cysticercal granuloma (figure 1). The patient was started on oxcarbazepine, which produced temporary control, with recurrence of jerky movements of her tongue lasting several minutes with frequent recurrence (videos 1 and 2 at Neurology.org). EEG did not show focal abnormalities (figure 2). The episodes were aborted by levetiracetam, $1 \mathrm{~g} / \mathrm{d}$, and escalation of oxcarbazepine dose to $900 \mathrm{mg} / \mathrm{d}$. Lingual epilepsia partialis continua occurs in Rasmussen encephalitis and herpes simplex encephalitis, but neurocysticercosis is an unusual cause. ${ }^{1,2}$

Figure 2 Ictal EEG

Supplemental data at Neurology.org

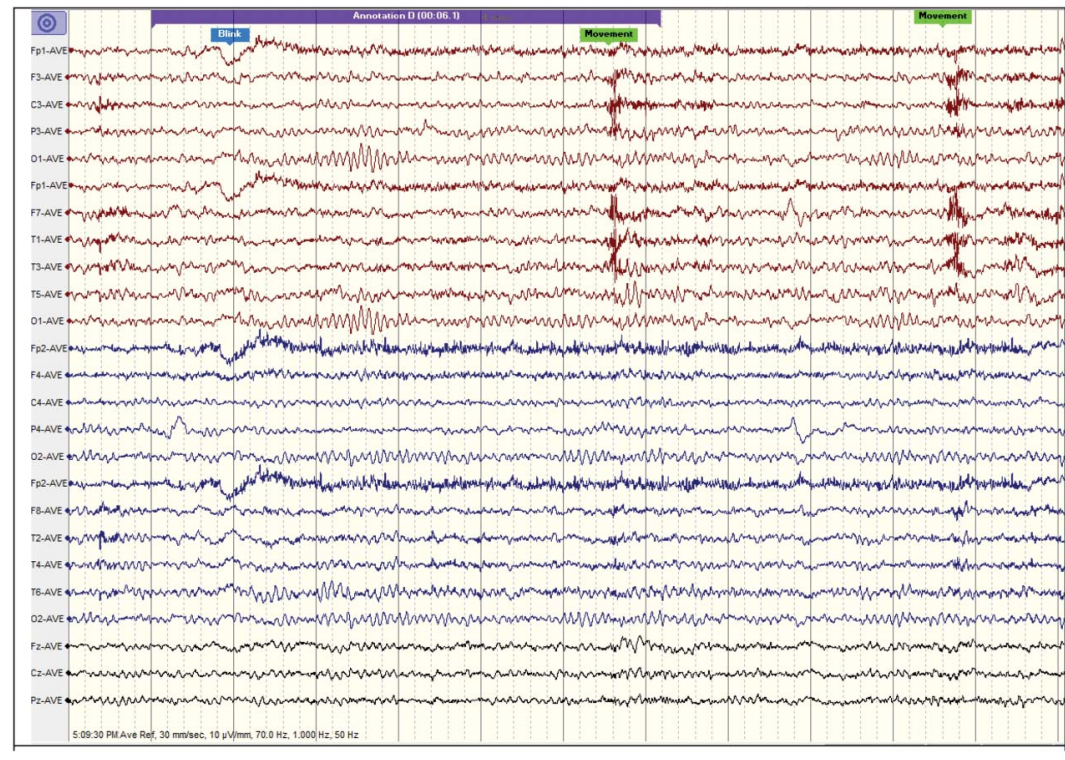

A 32-channel ictal EEG record shows EMG artifacts only. 
Sachin Sureshbabu, MD, DM, Dinesh Nayak, MD, DM, Gaurav Mittal, MD, DM, Sudhir Peter, MD, Chindripu Sobhana, MD, Vikash Aggarwal, MD, DM

From St. Stephen's Hospital (S.S., D.N., G.M., S.P., C.S., V.A.), New Delhi; Fortis Malar Hospital (D.N., V.A.), Adayar, Chennai; and Metropolis Labs (S.P., C.S.), Mumbai, India.

Author contributions: Sachin Sureshbabu: study concept, design, analysis of data, writing of manuscript. Dinesh Nayak: study design, analysis of data, writing of manuscript. Gaurav Mittal: study design, writing of manuscript. Sudhir Peter: study design, writing of manuscript. Chindriupu Sobhana: study design, writing of manuscript. Vikash Aggarwal: study design, writing of manuscript. Acknowledgment: The authors thank Dr. Sudhir C. Joseph, Director, St. Stephen's Hospital.

Study funding: No targeted funding reported.

Disclosure: The authors report no disclosures relevant to the manuscript. Go to Neurology.org for full disclosures.

Correspondence to Dr. Sureshbabu: drsachins1@rediffmail.com

1. Nayak D, Abraham M, Kesavadas C, Radhakrishnan K. Lingual epilepsia partialis continua in Rasmussen's encephalitis. Epileptic Disord 2006;8:114-117.

2. Iyer RS, Ramalingam Ramakrishnan TC. Lingual epilepsia partialis continua as the presenting manifestation of herpes simplex encephalitis: uncommon presentation of a common disease. Neurol India 2014;62:439-441.

\section{Carry the Only Card that Helps Support the AAN—and Get a \$100 Cash Rewards Bonus!}

Apply for the BankAmericard Cash Rewards ${ }^{\mathrm{TM}}$ credit card today to start getting more cash back for the things you buy most—plus a $\$ 100$ cash rewards bonus offer! Visit AAN.com/view/CashRewards and enter priority code "VACN51."

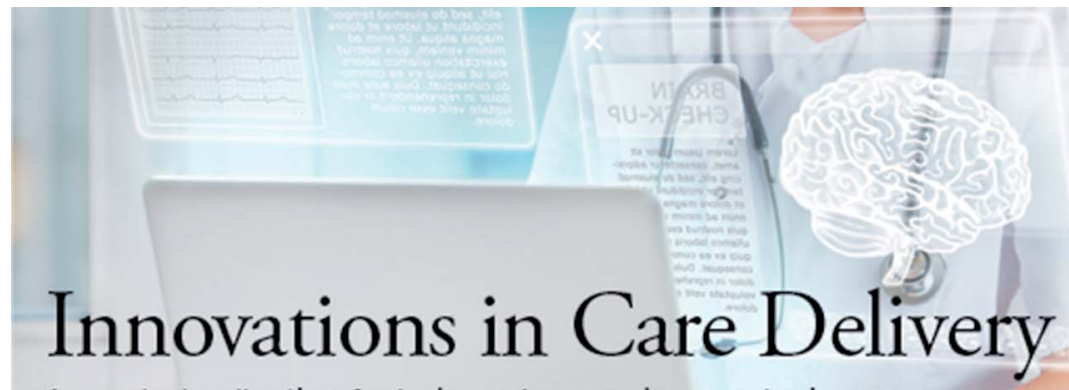

A curated collection featuring advances in neurologic care

\section{NEW! \\ Innovations in Care Delivery - A curated collection featuring advances in neurologic care}

This Neurology ${ }^{\circledR}$ special interest Web site provides a forum to explore new care models from multiple disciplines, access to sources on health care innovation, and expert opinions on current research from Neurology journals. Curated by Brian C. Callaghan, MD, and Kevin A. Kerber, MD.

Stay ahead of the curve at Neurology.org/innovations. 


\section{Neurology}

\section{Lingual epilepsia partialis continua in neurocysticercosis \\ Sachin Sureshbabu, Dinesh Nayak, Gaurav Mittal, et al. \\ Neurology 2017;88;108-109 \\ DOI 10.1212/WNL.0000000000003460}

This information is current as of December 26, 2016

Updated Information \&
Services
Supplementary Material

References

Subspecialty Collections

Permissions \& Licensing

Reprints including high resolution figures, can be found at: http://n.neurology.org/content/88/1/108.full

Supplementary material can be found at: http://n.neurology.org/content/suppl/2016/12/27/WNL.0000000000003 460.DC1

This article cites 2 articles, 0 of which you can access for free at: http://n.neurology.org/content/88/1/108.full\#ref-list-1

This article, along with others on similar topics, appears in the following collection(s):

All Clinical Neurology

http://n.neurology.org/cgi/collection/all_clinical_neurology

All Epilepsy/Seizures

http://n.neurology.org/cgi/collection/all_epilepsy_seizures

All Imaging

http://n.neurology.org/cgi/collection/all_imaging

Parasitic infections

http://n.neurology.org/cgi/collection/parasitic_infections

Video/ EEG use in epilepsy

http://n.neurology.org/cgi/collection/video_eeg_use_in_epilepsy

Information about reproducing this article in parts (figures,tables) or in its entirety can be found online at:

http://www.neurology.org/about/about_the_journal\#permissions

Information about ordering reprints can be found online:

http://n.neurology.org/subscribers/advertise

Neurology ${ }^{\circledR}$ is the official journal of the American Academy of Neurology. Published continuously since 1951 , it is now a weekly with 48 issues per year. Copyright @ 2016 American Academy of Neurology. All rights reserved. Print ISSN: 0028-3878. Online ISSN: 1526-632X.

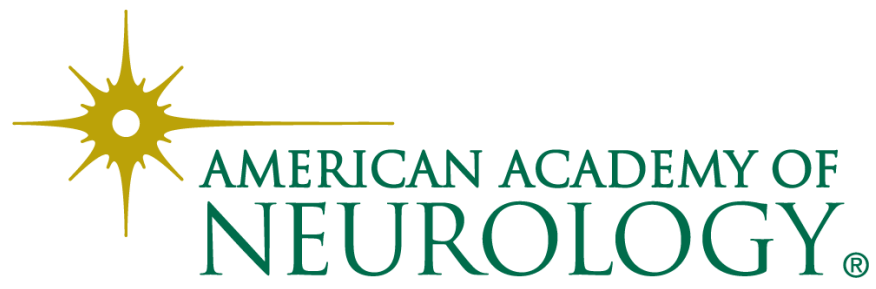

